\title{
Structure and dynamics of the community of periphytic algae in a subtropical reservoir (state of São Paulo, Brazil)
}

\author{
Ricardo Hideo Taniwaki ${ }^{1,4}$, Tatiana Cintra Borghi², Albano Geraldo Emílio Magrin², \\ Maria do Carmo Calijuri ${ }^{3}$, Flávia Bottino ${ }^{3}$ and Viviane Moschini-Carlos ${ }^{1}$
}

Received: 18 June, 2012. Accepted: 04 June, 2013

\begin{abstract}
Much remains to be learned about biological diversity, which constitutes a valuable natural resource. Due to the pressure that human activity has put on natural resources, biodiversity has been reduced, often unbeknownst to those responsible for that activity. Therefore, we aimed to perform a quantitative and qualitative analysis of periphytic algae in the Itupararanga reservoir, correlating the results with the physical and chemical characteristics of the water, as well as with climatic conditions. To that end, five samples were collected at four sampling stations in the Itupararanga reservoir during the year 2010. Aquatic macrophytes were collected with a $156-\mathrm{cm}^{2}$ frame, and the periphytic algae were scraped free of the macrophytes with a brush. Samples were fixed in formaldehyde and Lugol's solution for the qualitative and quantitative analyses, respectively. We identified 156 taxa belonging to eight classes, and the overall density was 10,200-171,800 individuals $/ \mathrm{mm}^{2}$. The taxonomic composition and abundance of periphyton were found to be dependent on spatial and temporal factors, such as the type of substrate and the characteristics of the sampling site, as well as seasonal variations in the chemical and physical properties of the water.
\end{abstract}

Key words: Periphyton, macrophytes, water quality, detrended correspondence analysis, principal components analysis

\section{Introduction}

Human activities such as agriculture and urbanization are the leading sources of nitrogen and phosphorus in freshwater ecosystems. An excess of those nutrients in surface waters causes a variety of problems, including eutrophication, harmful algal blooms, decreased concentrations of dissolved oxygen, fish kill and a loss of biodiversity (Carpenter et al. 1998).

Biodiversity constitutes a valuable resource in social, educational, cultural and scientific terms (Dudgeon et al. 2006). The loss of aquatic biodiversity is one of the greatest problems currently caused by human activity, because of the need to use hydric resources for multiple purposes. The consequences of this process for the functioning of freshwater ecosystems are still unknown (Giller et al. 2004). Among the main causes of the loss of aquatic biodiversity are changes in trophic status (Pusceddu et al. 2007), the use of pesticides (Relyea 2005), the construction of reservoirs (Power et al. 1996) and changes in land use in the watershed (Alin et al. 2002). In this context, knowledge of biodiversity is of extreme importance, considering that several organisms can be used as bioindicators of water quality, such as fish (e.g., Roche \& Boge 1996), benthic macroinvertebrates (e.g., Buss \& Borges 2008) and periphyton (e.g., Montuelle et al. 2010; Verb \& Vis 2005).

In Brazil, the periphytic community has gained attention because of its great potential as a bioindicator of water quality, as seen, for example, in the studies of Lobo \& Torgan (1988) and Lobo et al. (1996). Lobo et al. (2004) proposed a method to evaluate the organic pollution and eutrophication of Brazilian freshwaters by evaluating communities of epilithic algae, thus creating the Biological Index of Water Quality. Studies of the periphytic community, carried out mainly in the states of Rio Grande do Sul and São Paulo, have shown clear evidence of the eutrophication of freshwaters and the relationship between periphytic algae and human activities (Hermany et al. 2006; Salomoni et al. 2006; Borduqui et al. 2008; Lobo et al. 2010; Salomoni et al. 2011).

In addition to its potential as a bioindicator, periphytic diversity has been studied in contexts such as comparisons of the flora in dry and rainy seasons (e.g., Vercellino \& Bicudo 2006), comparisons of floristic similarity between lotic and lentic environments (e.g., Rodrigues \& Bicudo 2001), as well as taxonomic studies (e.g., Ferragut et al. 2005; Bicudo et al. 2007; Bicudo \& Menezes, 2006). Therefore,

\footnotetext{
${ }^{1}$ Universidade Estadual Paulista "Júlio de Mesquita Filho" Sorocaba, SP, Brazil

${ }^{2}$ Universidade Federal de São Carlos, Sorocaba, São Paulo, Brazil

${ }^{3}$ Escola de Engenharia de São Carlos, Departamento de Engenharia Hidráulica e Saneamento, São Carlos, SP, Brazil

${ }^{4}$ Author for correspondence: rht.bio@gmail.com
} 
the aim of this study was to determine the effect that climatological variables, as well as physical and chemical variables of the water, have on the taxonomic composition and abundance of periphytic algae adhered to natural substrates in a freshwater reservoir in Brazil.

\section{Material and methods}

The Itupararanga reservoir, located in the municipality of Ibiúna, in the state of São Paulo, Brazil, is at the source of the Sorocaba river, in the southeastern (subtropical) region of Brazil. It receives the waters of the Sorocabuçu and Sorocamirim rivers, which merge to form the Sorocaba river (Smith \& Petrere-Jr 2008). The reservoir was created in 1914 in order to generate electricity (Cunha \& Calijuri 2011) and borders on the municipalities of Ibiúna, Piedade, São Roque, Mairinque, Alumínio and Votorantim.

The main types of land use in the reservoir watershed (upper Sorocaba river and middle Tietê river areas) are (intense) agricultural activities on large plantations $\left(393 \mathrm{~km}^{2}\right)$ and small farms $\left(35 \mathrm{~km}^{2}\right)$, the largest area being cultivated for the commercial production of vegetables (Conceição et al. 2011).

The right bank is distinguished by a dense area of vegetation characterized as seasonal semideciduous forest. According to Cunha \& Calijuri (2011), this reservoir supplies potable water for approximately 800,000 people, has a storage capacity of 286 million $\mathrm{m}^{3}$ of water and a water retention time of 4 to 13 months depending on the precipitation patterns.

Over the course of the year 2010, we obtained seasonal samples of periphyton at four sampling stations within the Itupararanga reservoir, designated TRANS, BR1, BR3 and BR4. Samples were collected in the months of February, April, June, September and November.

The TRANS sampling station is located upstream of the reservoir, at the mouths of the Sorocabuçu and Sorocamirim rivers (23K 02722337384786 ). This station has a large population of aquatic macrophytes dominated by Eichhornia spp. and low coverage of riparian vegetation. Sampling stations BR1 and BR3 are located, respectively, at the mouth of Campo Verde creek (23K 0266956 7385031) and Ressaca creek (23K 02644307381817 ). Both have populations of aquatic macrophytes dominated by Polygonum punctatum Elliot, and their surroundings are characterized by low coverage of riparian vegetation and occupation by agriculture and housing. Sampling station BR4, at the mouth of Paruru creek (23K 0259767 7380366), is located downstream of the reservoir and closest to the dam. It has a population of aquatic macrophytes dominated by Eichhornia spp., and its surroundings are occupied mainly by agriculture and housing.

At the macrophyte stands, we obtained in situ measurements of $\mathrm{pH}$, electrical conductivity, temperature $\left({ }^{\circ} \mathrm{C}\right)$ and dissolved oxygen concentration, using two commercially available probes, one that measures the first three variables (model 63, 50 ft. cable; YSI Inc., Yellow Springs, OH, USA) and one that measures only dissolved oxygen (model 55, 12 $\mathrm{ft}$. cable; YSI Inc.) Water transparency was determined with a Secchi disk. Climatological (monthly precipitation) data were obtained from the website of the Integrated Center of Agrometeorological Information, which provides data from the climatological station at the municipality of Ibiúna (CIIAGRO, 2011).

In surface water samples examined in the laboratory, we determined the total nutrients (total nitrogen and total phosphorus) and dissolved nutrients (orthophosphate, nitrite and nitrate) following the recommendations of and methods established by the American Public Health Association (APHA 2005).

For the analyses of species composition and density of the periphytic community, we collected three samples from each sampling station in each of the months evaluated. In each sampling, a $156-\mathrm{cm}^{2}$ frame was used in order to collect samples of the periphyton adhered to the dominant macrophyte. The material collected was immediately put into polyethylene flasks containing distilled water and then transferred to insulated bags for subsequent processing in the laboratory, where the periphyton was separated from the macrophytes by scraping with a brush and jets of distilled water, and the volume was standardized for one liter. The material was preserved in $4 \%$ formaldehyde for the qualitative analyses and in Lugol's solution for the quantitative analyses.

The richness of species of periphytic algae was measured by the number of taxa, counted by cell unit, with Zeiss microscopes (Axio Imager. A1 and Axio Scope. A1; Carl Zeiss, Oberkochen, Germany), and identified with the aid of the studies conducted by Souza \& Moreira-Filho (1999), Magrin \& Senna (2000a), Magrin \& Senna (2000b), Taniguchi et al. (2003), Silva \& Cecy (2004), Ferragut et al. (2005), Elkis \& Bicudo (2006), Bicudo \& Menezes (2006), Bicudo et al. (2007), Alves-da-Silva \& Fortuna (2008), Oliveira et al. (2008), Dellamano-Oliveira et al. (2008), Bortolini et al. (2009) and Fontana \& Bicudo (2009). We adopted the classification system devised by Round (1965), following the recommendations of Bicudo \& Menezes (2006). To count the filamentous algae, such as Oedogonium spp., each $10 \mu \mathrm{m}$ of the filament was considered a cell unit. We quantified algal density using the Ütermohl counting procedure (Lund et al. 1958) under an inverted microscope (Axiovert 40; Carl Zeiss) with the aid of the American Public Health Association formula for the inverted microscope method of counting (APHA 2005).

The dominance and abundance of species were established according to the criteria established by Lobo \& Leighton (1986), in which dominant species are defined as those at densities above $50 \%$ of the total density of species in the sample, and abundant species are defined as those that occur above the mean value, obtained by dividing the total density by the number of species in the sample. 
Using the population density data, we calculated the indices of species diversity (Shannon-Wiener 1949, cited in Margurran 1991) and uniformity (Pielou 1969, cited in Margurran 1991). Those indices are based on the ShannonWiener function, being therefore less dependent on the sample size, and are usually employed in studies of communities of adhered algae.

During the month of September, we were unable to sample the Ressaca and Paruru creeks because of the low level of the reservoir, which made it impossible to access the sampling station by boat. The same occurred in November at the sampling stations on the Campo Verde and Paruru creeks.

Principal components analysis (PCA) and detrended correspondence analysis (DCA) were applied to reduce the dimensionality of the data. In the environmental matrix, we considered the variables $\mathrm{pH}$, electrical conductivity, dissolved oxygen, water transparency, total nitrogen, total phosphorus and precipitation. In the biological matrix, we considered the density of periphytic algae (10 most abundant species in the study period). The data of the environmental matrix were used to perform the PCA, whereas the data of the environmental and biological matrices were used to perform the DCA. The analyses were carried out with matrix correlation methods using the software PAST (Hammer et al. 2001), and Pearson's correlation test was applied.

\section{Results}

In 2010, the monthly precipitation at the Itupararanga reservoir peaked at $342.8 \mathrm{~mm}$ (in January), the least accumulation being $3.6 \mathrm{~mm}$ (in August), with a clear separation between the rainy season (January-April and SeptemberDecember) and the dry season (May-August). The water transparency (Secchi depth) ranged from $0.2 \mathrm{~m}$ to $2.1 \mathrm{~m}$ and was greatest in the months of February, March and April (during the rainy season).

As can be seen in Tab. 1, the water temperature ranged from a high of $29.1^{\circ} \mathrm{C}$ (in February) to a low of $14.3^{\circ} \mathrm{C}$ (in June). Over the course of the year, the $\mathrm{pH}$ ranged from 6.1 to 9.8 and the concentration of dissolved oxygen in the water ranged from $1.5 \mathrm{mg} \mathrm{L}^{-1}$ to $9.1 \mathrm{mg} \mathrm{L}^{-1}$. The electrical conductivity ranged from $37 \mu \mathrm{S} \mathrm{cm}^{-1}$ to $99 \mu \mathrm{S} \mathrm{cm}^{-1}$, the highest values being recorded at the TRANS and BR4 stations.

Total phosphorus ranged from $20.4 \mu \mathrm{g} \mathrm{L}^{-1}$ to $126.1 \mu \mathrm{g} \mathrm{L}^{-1}$, and total nitrogen ranged from undetectable to $0.47 \mathrm{mg} \mathrm{L}^{-1}$. The concentration of total dissolved phosphate ranged from undetectable to $31.3 \mu \mathrm{g} \mathrm{L}^{-1}$. The level of orthophosphate (inorganic dissolved phosphorus) ranged from $0.9 \mu \mathrm{g} \mathrm{L} \mathrm{L}^{-1}$ to $7.2 \mu \mathrm{g} \mathrm{L}^{-1}$. The level of nitrate ranged from $0.31 \mu \mathrm{g} \mathrm{L} \mathrm{L}^{-1}$ to $0.84 \mu \mathrm{g} \mathrm{L}^{-1}$, and the level of nitrite ranged from undetectable to $1.03 \mu \mathrm{g} \mathrm{L} \mathrm{L}^{-1}$. The concentrations of total dissolved

Table 1. Physical and chemical variables related to the water in the Itupararanga reservoir, in the state of São Paulo, Brazil, between February and November of 2010.

\begin{tabular}{|c|c|c|c|c|c|c|c|c|c|c|c|}
\hline Station-month & $\begin{array}{c}\mathrm{T} \\
\left({ }^{\circ} \mathrm{C}\right)\end{array}$ & $\mathrm{pH}$ & $\begin{array}{c}\mathrm{EC} \\
\left(\mu \mathrm{S} \mathrm{cm}^{-1}\right)\end{array}$ & $\begin{array}{l}\mathrm{zSD} \\
(\mathrm{m})\end{array}$ & $\begin{array}{c}\mathrm{DO} \\
\left(\mathrm{mg} \mathrm{L}^{-1}\right)\end{array}$ & $\begin{array}{c}\mathrm{TP} \\
\left(\mu \mathrm{g} \mathrm{L}^{-1}\right)\end{array}$ & $\begin{array}{c}\text { TDP } \\
\left(\mu \mathrm{g} \mathrm{L}^{-1}\right)\end{array}$ & $\begin{array}{c}\text { OP } \\
\left(\mu \mathrm{g} \mathrm{L}^{-1}\right)\end{array}$ & $\begin{array}{c}\mathrm{TN} \\
\left(\mathrm{mg} \mathrm{L}^{-1}\right)\end{array}$ & $\begin{array}{c}\mathrm{NO}_{2}^{-} \\
\left(\mathrm{mg} \mathrm{L}^{-1}\right)\end{array}$ & $\begin{array}{c}\mathrm{NO}_{3}^{-} \\
\left(\mu \mathrm{g} \mathrm{L}^{-1}\right)\end{array}$ \\
\hline TRANS-Feb. & 27.70 & 8.23 & 64.00 & 1.50 & 8.38 & 126.13 & 31.31 & 7.24 & 0.16 & 0.04 & 0.64 \\
\hline BR1-Feb. & 28.81 & 8.19 & 50.00 & 1.70 & 7.40 & 26.26 & 19.20 & 3.82 & 0.43 & 0.04 & 0.52 \\
\hline BR3-Feb. & 29.14 & 9.80 & 52.00 & 1.60 & 7.90 & 29.42 & 15.04 & 2.25 & 0.48 & 0.01 & 0.51 \\
\hline BR4-Feb. & 29.04 & 7.67 & 70.00 & 1.40 & 6.83 & 25.15 & 15.15 & 3.01 & 0.37 & 0.04 & 0.46 \\
\hline TRANS-Apr. & 20.80 & 6.62 & 70.70 & 2.00 & 1.92 & 29.74 & 9.07 & 2.18 & * & 0.13 & 0.43 \\
\hline BR1-Apr. & 24.40 & 7.23 & 63.20 & 2.00 & 6.28 & 23.60 & 10.16 & 3.49 & 0.12 & 0.06 & 0.43 \\
\hline BR3-Apr. & 23.40 & 6.76 & 66.00 & 1.50 & 6.46 & 20.45 & 3.08 & 1.26 & 0.17 & 0.03 & 0.42 \\
\hline BR4-Apr. & 22.60 & 6.92 & 99.20 & 2.10 & 5.60 & 25.41 & 8.73 & 2.85 & * & 0.42 & 0.42 \\
\hline TRANS-Jun. & 14.30 & 6.52 & 67.60 & 1.10 & 4.20 & 55.79 & 16.16 & 4.01 & 0.14 & 0.49 & 0.47 \\
\hline BR1-Jun. & 18.00 & 6.88 & 62.70 & 1.70 & 6.09 & 32.66 & 20.71 & 1.38 & 0.14 & 0.22 & 0.31 \\
\hline BR3-Jun. & 19.10 & 7.34 & 64.30 & 1.10 & 8.53 & 113.61 & 12.46 & 0.96 & 0.23 & 0.16 & 0.34 \\
\hline BR4-Jun. & 16.80 & 7.07 & 78.40 & 1.10 & 7.13 & 20.59 & 8.06 & 7.08 & 0.09 & 1.03 & 0.57 \\
\hline TRANS-Sep. & 18.90 & 6.10 & 70.60 & 0.80 & 8.90 & 33.18 & 0.00 & 2.46 & 0.12 & 0.36 & 0.77 \\
\hline BR1-Sep. & 19.60 & 7.34 & 60.20 & 0.50 & 9.13 & 49.12 & 14.27 & 2.59 & * & * & 0.37 \\
\hline TRANS-Nov. & 21.30 & 6.60 & 89.80 & 0.85 & 5.30 & 54.35 & 0.00 & 3.24 & * & 0.46 & 0.71 \\
\hline BR3-Nov. & 22.30 & 7.50 & 37.00 & 0.20 & 1.50 & 89.27 & 17.10 & 2.13 & * & 0.07 & 0.84 \\
\hline Mean & 22.26 & 7.29 & 66.61 & 1.38 & 6.34 & 47.17 & 12.54 & 3.12 & 0.15 & 0.22 & 0.51 \\
\hline CV (\%) & 20.53 & 12.13 & 22.03 & 45.03 & 35.68 & 71.26 & 63.93 & 57.70 & 100.15 & 123.44 & 30.13 \\
\hline
\end{tabular}

T - water temperature; EC - electrical conductivity; zSD - Secchi depth (water transparency); DO - dissolved oxygen; TP - total phosphorus; TDP - total dissolved phosphorus; OP -orthophosphate; TN - total nitrogen; $\mathrm{NO}_{2}{ }^{-}-$nitrite; $\mathrm{NO}_{3}{ }^{-}$- nitrate; TRANS - upstream of the reservoir (at the confluence of the Sorocabuçu and Sorocamirim rivers); BR1 - in the central portion of the reservoir (at the mouth of Campo Verde creek); BR3 - in the central portion of the reservoir (at the mouth of Ressaca creek); BR4 - downstream of the reservoir (at the mouth of Paruru creek); CV coefficient of variation.

${ }^{*}$ Below the detection limit of the method employed. 
phosphate, orthophosphate and nitrate were lower during the dry season (Tab. 1).

Regarding the taxonomic composition of the periphyton, in the total study period we found 156 taxa, divided in 8 classes, with 51 species of the class Bacillariophyceae, 27 of Chlorophyceae, 1 of Coleochaetophyceae, 18 of Cyanophyceae, 2 of Dinophyceae, 10 of Euglenophyceae, 11 of Oedogoniophyceae and 36 of Zygnemaphyceae.

At sampling station TRANS, there was a predominance of class Cyanophyceae, with 2 species of higher representativeness in the group: Pseudanabaena cf. moniliformis Komárek \& Kling, categorized as abundant during the months of February, April and June; and Komvophoron schmidlei Anagnostidis \& Komárek, categorized as abundant during February. At the second place in representativeness was class Bacillariophyceae, with the species Fragilaria delicatissima var. delicatissima Lange-Bertalot, categorized as abundant during the months of September and October. The abundance of the class Cyanophyceae increased progressively between February and June, decreasing in the months of September and November (Fig. 1). In total, 14 species were categorized as abundant at this sampling station.
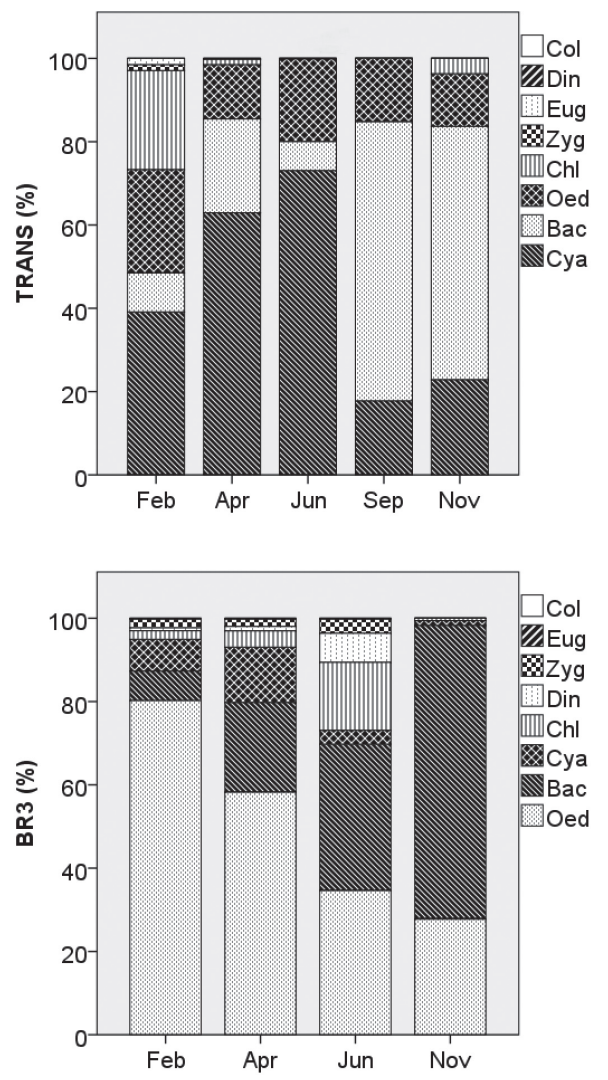

Figure 1. Classes of periphytic algae (\%) at different sampling stations and in different sampling periods in the Itupararanga reservoir, state of São Paulo, Brazil.

TRANS - sampling station upstream of the reservoir (at the confluence of the Sorocabuçu and Sorocamirim rivers); BR1 sampling station in the central portion of the reservoir (at the mouth of Campo Verde creek); BR3 - sampling station in the central portion of the reservoir (at the mouth of Ressaca creek); BR4 - sampling station downstream of the reservoir (at the mouth of Paruru creek); Col - Coleochaetophyceae; Din - Dinophyceae; Eug - Euglenophyceae; Zyg - Zygnemaphyceae; Chl - Chlorophyceae; Oed - Oedogoniophyceae; Bac - Bacillariophyceae; Cya - Cyanophyceae. 
var. ambigua (categorized as abundant in June). During the study period, there was a gradual decrease in the abundance of Oedogoniophyceae and a gradual increase in that of Bacillariophyceae (Fig. 1). In total, 11 species were categorized as abundant at this sampling station.

At sampling station BR4, Bacillariophyceae was the predominant class, with abundance of the species $F$. delicatissima var. delicatissima and A. minutissimum during February, April and June. Ranking second, the class Oedogoniophyceae was categorized as predominant and abundant during February, April and June. Throughout the study period, there was a gradual increase of Bacillariophyceae and gradual decrease of Oedogoniophyceae, as observed in Fig. 1. In total, 7 species were categorized as abundant at this sampling station.

The total species richness, calculated monthly for each sampling station, ranged from 5 to 41 , and sampling station TRANS showed the lowest and highest monthly values (5 species and 41 species). At all sampling stations, species richness was highest during the rainy season (in February: TRANS $=41$ species; $B R 1=32$ species; $B R 3=28$ species; and BR4 $=32$ species), decreasing progressively until the arrival of the dry season (in June: TRANS $=5$ species;
$\mathrm{BR} 1=18$ species; $\mathrm{BR} 3=26$ species; and $\mathrm{BR} 4=13$ species). Thereafter, species richness increased at sampling station TRANS (from 5 species in September to 10 species in November) and at sampling station BR1 (September $=27$ ), whereas it decreased at sampling station BR3 (6 species in November).

Using the Shannon index, we determined that, at sampling stations TRANS and BR4, diversity was greatest in February. At sampling station BR1, the Shannon index was highest in September, whereas it was highest in June at sampling station BR3 (Fig. 2).

Using the Pielou's evenness index, we found that uniformity in the distribution of the number of individuals within species was highest in June at sampling stations BR1, BR3 and BR4, whereas it was highest in September at sampling station TRANS (Fig. 2)

In the PCA of the physical and chemical data related to the water, together with the climatological data, the first two axes explained $60 \%$ of the overall variability of the data, with a temporal pattern. In axis 1 (explaining 38.8\%), the sampling stations were separated according to the sampling period (Fig. 3). The variables that separated the February samplings from those of the other months were mainly precipitation, temperature, $\mathrm{pH}$ and total nitrogen. In axis 2
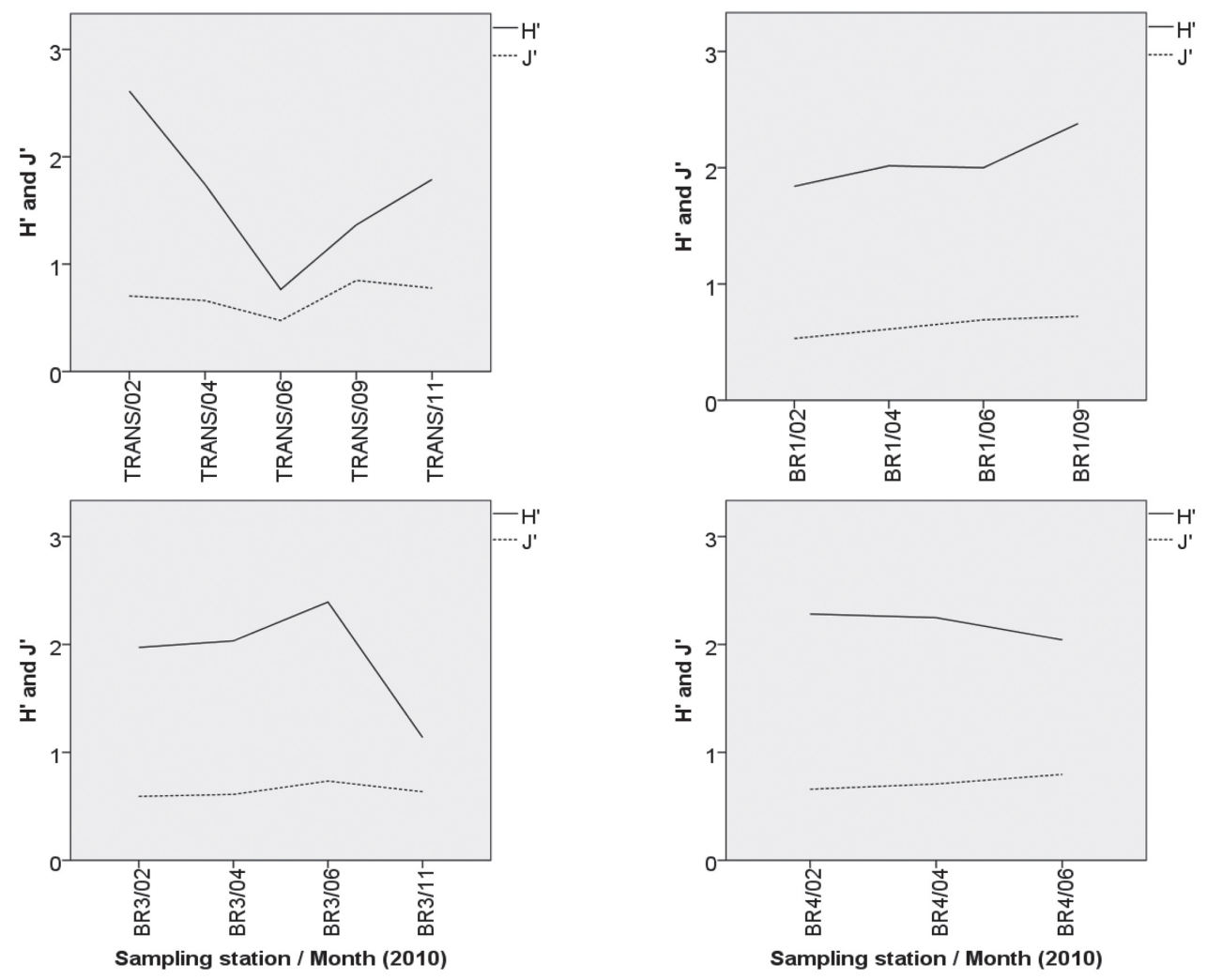

Figure 2. Representation of the Shannon diversity index ( $\left.\mathrm{H}^{\prime}\right)$ and evenness index (J') indices at different sampling stations and in different sampling periods in the Itupararanga reservoir, state of São Paulo, Brazil.

TRANS - sampling station upstream of the reservoir (at the confluence of the Sorocabuçu and Sorocamirim rivers); BR1 sampling station in the central portion of the reservoir (at the mouth of Campo Verde creek); BR3 - sampling station in the central portion of the reservoir (at the mouth of Ressaca creek); BR4 - sampling station downstream of the reservoir (at the mouth of Paruru creek). 


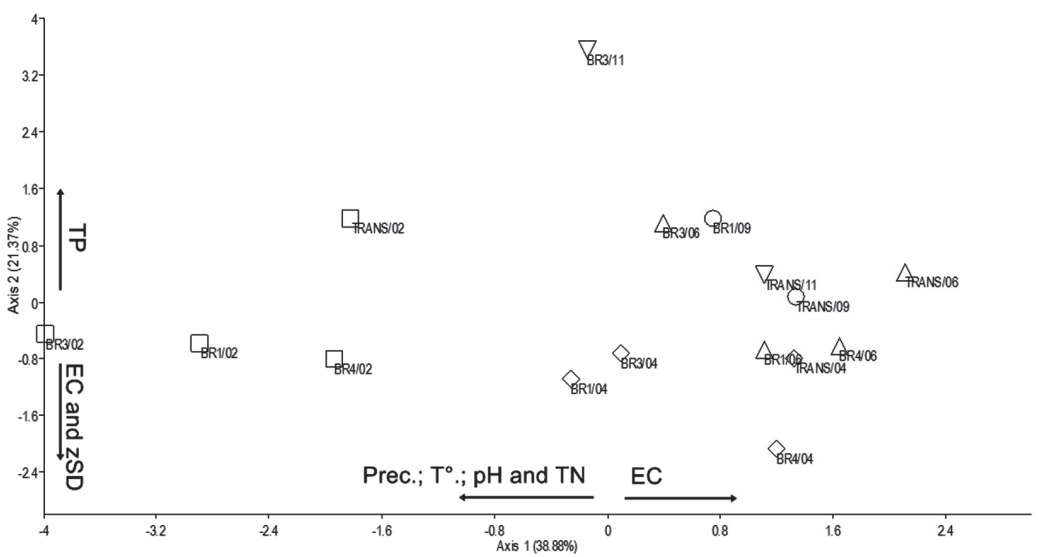

Figure 3. Graphical representation of the first two axes of the principal components analysis applied to the data obtained for periphytic algae in the Itupararanga reservoir, state of São Paulo, Brazil. zSD - Secchi depth (water transparency); TP - total phosphorus; $\mathrm{T}^{\circ}$ - water temperature; $\mathrm{TN}$ - total nitrogen; Prec. - precipitation; EC - electrical conductivity.

(explaining 21.3\%), the sampling stations were separated according to the seasonality and to the physical and chemical characteristics of the water. The months of September and November were separated according to the concentration of phosphorus, whereas the remaining months were separated mainly according to water transparency and conductivity (Fig. 3). The individual contributions of the variables to the first two axes of the principal components analysis are shown in Tab. 2.

In the DCA (Fig. 4), which was based on the values of density of the periphytic community (10 most abundant species) at the different sampling stations and in the different sampling periods, axes 1 and 2 were retained, with eigenvalues of 0.66 and 0.16 , respectively, and the pattern was mainly influenced by the spatial factor.

The graphical representation of the DCA (Fig. 4) indicates that the species Pseudanabaena cf. moniliformis is characteristic of sampling station TRANS, whereas Achnanthidium minutissimum and Fragilaria delicatissima var. delicatissima are characteristic of sampling station BR4. Species of the genus Oedogonium were mainly grouped at sampling stations BR1 and BR3.

Table 2. Contributions of the variables to the first two axes of the principal components analysis applied to the data obtained for periphytic algae in the Itupararanga reservoir, state of São Paulo, Brazil.

\begin{tabular}{lcc}
\hline Variable & Axis 1 & Axis 2 \\
\hline Precipitation & -0.63 & 0.20 \\
Temperature & -0.91 & -0.14 \\
$\mathrm{pH}$ & -0.90 & 0.07 \\
Electrical conductivity & 0.50 & -0.57 \\
Water transparency & -0.21 & -0.82 \\
Dissolved oxygen & -0.30 & -0.16 \\
Total phosphorus & -0.05 & 0.74 \\
Total nitrogen & -0.80 & -0.21 \\
\hline
\end{tabular}

Using Pearson's correlation test, we found no significant correlation between the values of axis 1 of the DCA and those of axis 1 of the PCA; nor did the abundance and diversity of the periphyton correlate significantly with the physical, chemical and climatological characteristics of the Itupararanga reservoir.

\section{Discussion}

On the basis of the climatological data, together with the data related to the physical and chemical characteristics of the water, we separated the study period into two components: a dry period (May through August); and a rainy period (bracketing the dry period, January through April and September through December).

Low water transparency was observed at all sampling stations, and the higher values observed during the months of February and April were associated with the higher values

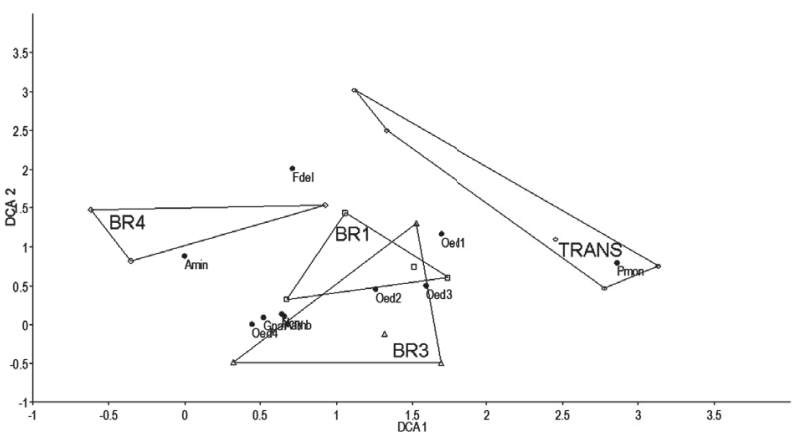

Figure 4. Graphical representation of the detrended correspondence analysis (DCA) applied to the data obtained for the 10 most abundant species of periphytic algae in the Itupararanga reservoir, state of São Paulo, Brazil.

Pmon - Pseudanabaena moniliformis; Fdel - Fragilaria delicatissima var. delicatissima; Amin - Achnanthidium minutissimum; Oed 1, 2, 3 and 4 Oedogonium spp. 
of precipitation, clearly indicating the influence of precipitation on water transparency.

The concentrations of total phosphorus and total nitrogen varied throughout the year, with two concentration peaks, one during the dry season and another during the rainy season. At sampling stations TRANS and BR4, total phosphorus concentrations were highest in February, as were precipitation values. Those two sampling stations were apparently most affected by human activities, including domestic effluents, and the availability of nutrients at the stations is directly influenced by the Sorocabuçu and Sorocamirim rivers, as well as by the Paruru creek. At sampling stations BR1 and BR3, the highest values of total phosphorus were found during the dry period, in June. Those two stations are located in the central portion of the reservoir and their surroundings are less populated.

The pattern of total nitrogen in the reservoir was similar to that of total phosphorus. However, at all sampling stations, the highest nitrogen concentrations were found in February and were associated with higher levels of precipitation, indicating the input of nitrogen-rich material into the reservoir. A second increase in nitrogen concentration was observed in July, albeit lower than the peak observed in February. This might indicate that there was internal regeneration of the nutrients at all sampling stations during the dry period, corroborating the findings reported by Nogueira et al. (1999) for the Jurumirim reservoir (also in the state of São Paulo).

Regarding the taxonomic composition, the richness of periphytic algae was similar to that observed in other studies in the state of São Paulo. In the lake located at the Fontes do Ipiranga State Park (state of São Paulo), which has oligotrophic characteristics, Vercellino \& Bicudo (2006) identified 112 taxa. In a study on the effects of phosphorus enrichment on the structure of the periphytic community in that same lake, Ferragut \& Bicudo (2009) identified 172 taxa.

In the Iraí reservoir (in the state of Paraná), Cetto et al. (2004) recorded 130 taxa. In a study of the cascade reservoirs on the Paranapanema river, Felisberto \& Rodrigues (2005) recorded 91 species in the dry period and 119 species in the rainy period.

At sampling station TRANS, we found that, between February and June, Cyanophyceae was the predominant class, followed by class Bacillariophyceae. In a study conducted in the Alto Paraná watershed, Fonseca \& Rodrigues (2007) reported that the abundance of periphytic cyanobacteria was indirectly characterized by the nutrient availability. The same was observed in the present study, nutrient availability being highest at sampling station TRANS.

The class Bacillariophyceae was dominant at sampling station BR4 throughout the study period, as well as at sampling stations TRANS, BR1 and BR3 during the months in which the water level of the reservoir was lowest (September and November). In a study conducted in the floodplain of the Alto Paraná river, Algarte et al. (2009) also found Bacillariophyceae to be the dominant class during the low-water period. According to those authors, Bacillariophyceae can be dominant during low-water periods because several species of this class have the capacity to occupy substrates rapidly and to develop under a variety of environmental conditions.

Large numbers of species of the class Oedogoniophyceae occurred at sampling stations BR1 and BR3. The organisms pertaining to this class are frequently found in warm, stable waters with low flow rates (Biggs \& Kilroy, 2000). Taniguchi et al. (2005) found that Oedogoniophyceae species grow at a high density on the petioles of the aquatic macrophyte Eichhornia azurea (Swartz) Kunth, attributing this to their high capacity to adhere to that substrate. In our study, the substrates available for periphytic colonization were the petioles of the aquatic macrophyte Polygonum punctatum, which possess a three-dimensional structure similar to that of the petioles of Eichhornia azurea, corroborating the findings of Taniguchi et al. (2005).

In June, the species Pseudanabaena cf. moniliformis and Achnanthidium minutissimum were dominant regarding species distribution. In studies using diatoms to detect human impacts in Brazil, Bere \& Tundisi (2011) and Lobo et al. (2004) found a relationship between the occurrence of the species Achnanthidium minutissimum and areas with degraded waters in the states of São Paulo and Rio Grande do Sul. In a study on the structure of the periphytic community on a seasonal scale in the Garças reservoir (also in the state of São Paulo), Borduqui et al. (2008) observed a dominance of Cyanobacteria during the dry season. These findings support our data, which indicate the same relationships between periphytic algae and environmental conditions.

At our sampling stations, the richness of the periphytic community was typically higher during the rainy season. At the Capivara reservoir, one of the cascade reservoirs of the Paraná river, Felisberto \& Rodrigues (2005) also found the diversity of the periphytic community to be higher during the rainy season, during which temperatures are higher, which might stimulate the development of other groups. Fermino et al. (2011), studying the effects of the addition of nutrients on the floristic composition of the periphyton in the Ninféias Reservoir (also in the state of São Paulo), found that the seasonal scale was one of the main determinants of periphytic diversity, species richness being highest during the summer and autumn (i.e., the wettest months). In the present study, the evenness of the periphytic community at sampling stations BR1, BR3 and BR4 was highest during the dry season. According to the evenness index, the evenness reflects the pattern of species distribution in each sample.

With the PCA, we determined that the physical and chemical characteristics of the water in reservoirs are mainly controlled by the seasonality and do not show spatial characteristics such as those described by Thornton et al. (1990). This can be attributed to the location of the sampling stations, which are not near the central channel of the reservoir but rather in the arms of the reservoir, at the mouths of the rivers that feed it. This condition is unfavorable for 
marked spatial patterns, because it is greatly influenced by the watershed of which the rivers are part, as well as by the land use within each watershed, as previously described by Cunha \& Calijuri (2011).

The DCA indicated that the species in the periphytic community display spatial patterns, in contrast with the physical and chemical characteristics of the water. This result can be associated with the type of substrate studied. As observed in the graphical representation of the DCA, sampling stations BR1 and BR3, which have the same type of substrate (P. punctatum), display an overlap of the convex hulls. In contrast, sampling stations TRANS and BR4 showed no such overlap but had very distinct characteristics, probably separated according to differences in nutrient concentrations.

Various studies have demonstrated that the type of substrate and its phenological characteristics can influence the richness of periphytic communities. Vieira et al. (2007) showed that the structural complexity of aquatic macrophytes interferes with the diversity of periphytic communities. A study comparing periphytic richness between two species of macrophytes showed that the structural characteristics of the macrophyte (plant density and texture), together with the physical and chemical characteristics of the water, determine the species composition of the periphyton (Messyasz \& Kuczynska-Kippen, 2006).

On the basis of our findings, we conclude that the algal composition of the periphytic community in the Itupararanga reservoir is controlled by space and time, owing to the distinct characteristics of each sampling station. The main influence on the sampling stations is the land use within their watersheds. We showed temporal and spatial variation in the dominance and diversity of species of periphytic algae. The composition and abundance of the algae was also influenced by the structural characteristics of the substrates colonized.

\section{Acknowledgments}

This study received financial support from the Brazilian Coordenação de Aperfeiçoamento de Pessoal de Nivel Superior (CAPES, Office for the Advancement of Higher Education; master's scholarship grant to RHT) and from the Fundação de Amparo à Pesquisa do Estado de São Paulo (FAPESP, São Paulo Research Foundation; Grant no. 2008/55636-9). The authors thank Prof. Dr. Maurício Cetra for assisting in the statistical analyses, as well as the peer reviewers for their important contributions to this manuscript.

\section{References}

Algarte, V.M.; Siqueira, N.S.; Murakami, E.A. \& Rodrigues, L. 2009. Effects of hydrological regime and connectivity on the interannual variation in taxonomic similarity of periphytic algae. Brazilian Journal of Biology 69(2): 609-616.
Alin, S.R.; O'reilly, C.M.; Cohen, A.S.; Dettman, D.L.; Palacios-Fest, M.R. $\&$ Mckee, B.A. 2002. Effects of land-use change on aquatic biodiversity: A view from the paleorecord at Lake Tanganyika, East Africa. Geology 30: 1143-1146.

Alves-da-Silva, S.M. \& Fortuna, J.R. 2008. O gênero Phacus (Euglenophyceae) em sistemas lênticos da Planície Costeira do Rio Grande do Sul, sul do Brasil. Acta Botanica Brasilica 22(3): 684-700.

APHA. 2005. Standard methods for the examination of water and wastewater. Ed. 21. Washington DC. American Public Health Association.

Bere, T. \& Tundisi, J. G. 2011. Applicability of borrowed diatom-based water quality assessment indices in streams around Sao Carlos-SP, Brazil. Hydrobiologia 673: 179-192.

Bicudo, C.E.M. \& Menezes, M. 2006. Gêneros de algas de águas continentais do Brasil. Chave de identificação e descrições. 2 ed. São Carlos, RiMa.

Bicudo, C.E.M.; Faustino, S.M.M.; Godinho, L.R. \& Oliveira, M. 2007. Criptógamos do Parque estadual das Fontes do Ipiranga, São Paulo, SP. Algas, 24: Zygnemaphyceae (Desmidiales: Octacanthium, Staurastrum e Staurodesmus). Hoehnea 34(4): 497-517.

Biggs, B.J.F \& Kilroy, C. 2000. Stream Periphyton Monitoring Manual. Christchurch, New Zealand. The New Zealand Ministry for the Environment. NIWA.

Borduqui, M.; Ferragut, C. \& Bicudo, C.E.M. 2008. Chemical composition and taxonomic structure vertical and seasonal variation of periphyton community in a shallow hypereutrophic reservoir. Garças Reservoir, São Paulo, Brazil. Acta Limnologica Brasiliensia 20: 381-392.

Bortolini, C.B.; Moresco, C.; Siqueira, N.S.; Biolo, S. \& Bueno, N.C. 2009. Closterium Nitzsch ex Ralfs (Desmidiaceae) em um lago artificial urbano, Paraná, Brasil. Hoenea 36(3): 445-454.

Buss, D.F. \& Borges, E.L. 2008. Application of Rapid Bioassessment Protocols (RBP) for benthic macroinvertebrates in Brazil: Comparison between sampling techniques and mesh sizes. Neotropical Entomology 37: 288-295.

Carpenter, S.R.; Caraco, N.F.; Correll, D.L.; Howarth, R.W.; Sharpley, A.N. \& Smith, V.H. 1998. Nonpoint pollution of surface waters with phosphorus and nitrogen. Ecological Applications 8: 559-568.

Cetto, J.M.; Leandrini, J.A.; Felisberto, S.A. \& Rodrigues, L. 2004. Periphyton algae community in Irai reservoir, Paraná state, Brazil. Acta Scientarum 26: 1-7.

CIIAGRO. 2011. Centro integrado de Informações agrometeorológicas. Disponível em www.ciiagro.sp.gov.br/ciiagroonline (Acesso em 01/12/2011).

Conceição, F.T.; Sardinha, D.D.; Navarro, G.R.B.; Antunes, M.L.P. \& Angelucci, V.A. 2011. Rainwater Chemical Composition and Annual Atmospheric Deposition at Alto Sorocaba Basin (Sp). Química Nova 34: 610-658.

Cunha, D.G.F. \& Calijuri, M.C. 2011. Limiting factors for phytoplankton growth in subtropical reservoirs: the effect of light and nutrient availability in different longitudinal compartments. Lake and Reservoir Management 27: 162-172.

Cunha, D.G.F. \& Calijuri, M.C. 2011. Seasonal variation of phytoplankton functional groups in the arms of a tropical reservoir with multiple uses (SP, Brazil). Acta Botanica Brasilica 25: 822-831.

Dellamano-Oliveira, M.J.; Sant'Anna, C.L.; Taniguchi, G.M. \& Senna, P.A.C. 2008. Os gêneros Staurastrum, Staurodesmus e Xanthidium (Desmidiaceae, Zygnemaphyceae) da Lagoa do Caçó, Estado do Maranhão, Nordeste do Brasil. Hoehnea 35(3): 333-350.

Dudgeon, D.; Arthington, A.H.; Gessner, M.O.; Kawabata, Z.I.; Knowler, D.J.; Leveque, C.; Naiman, R.J.; Prieur-Richard, A.H.; Soto, D.; Stiassny, M.L.J. \& Sullivan, C.A. 2006. Freshwater biodiversity: importance, threats, status and conservation challenges. Biological Reviews 81: 163-182.

Elkis, I.C. \& Bicudo, C.E.M. Criptógamos do Parque Estadual das Fontes do Ipiranga, São Paulo, SP. Algas, 23: Oedogoniophyceae. Hoehnea 33(4): 511-520.

Felisberto, S.A. \& Rodrigues, L. 2005. Periphytic community of reservoirs cascade in the Paranapanema river, Brazil. Acta Scientiarum - Biological Sciences 27: 215-223. 
Fermino, F.S.; Bicudo, C.E.M. \& Bicudo, D.C. 2011. Seasonal influence of nitrogen and phosphorus enrichment on the floristic composition of the algal periphytic community in a shallow tropical, mesotrophic reservoir (São Paulo, Brazil). Oecologia Australis 15: 476-493.

Ferragut, C. \& Bicudo, D.C. 2009. Effect of different levels of phosphorus enrichment on periphyton community structure in a tropical oligotrophic reservoir (São Paulo, Brazil). Acta Limnologica Brasiliensia 32: 571-585.

Ferragut, C.; Lopes, M.R.M.; Bicudo, D.C.; Bicudo, C.E.M. \& Vercellino, I.S. Ficoflórula perifítica e planctônica (exceto Bacillariophyceae) de um reservatório oligotrófico raso (Lago do IAG, São Paulo). Hoehnea 32(2): 137-184.

Fonseca, I.A. \& Rodrigues, L. 2005. Comunidade de algas perifíticas em distintos ambientes da planície de inundação do alto rio Paraná. Acta Scientiarum. Biological Sciences 27(1): 21-28.

Fontana, L. \& Bicudo, D.C. 2009. Diatomáceas (Bacillariophyceae) de sedimentos superficiais dos reservatórios em cascata do Rio Paranapanema (SP/PR, Brasil): Coscinodiscophyceae e Fragilariophyceae. Hoehnea 36(3): 375-386

Giller, P.S.; Hillebrand, H.; Berninger, U.G.; Gessner, M.O.; Hawkins, S.; Inchausti, P.; Inglis, C.; Leslie, H.; Malmqvist, B.; Monaghan, M.T.; Morin, P.J. \& O'mullan, G. 2004. Biodiversity effects on ecosystem functioning: emerging issues and their experimental test in aquatic environments. Oikos 104: 423-436.

Hammer, Ø.; Harper, D.A.T. \& Ryan, P.D. 2001. PAST: Palaeontological statistics software package for education and data analysis. Paleontologia Electronica 4: $9 \mathrm{http}: / /$ palaeo-electronica.org/2001_1/past/ issue1_01.htm.

Hermany, G.; Schwarzbold, A.; Lobo, E.A. \& Oliveira, M.A. 2006. Ecology of epilithic diatom community in a low-order stream system of the Guaíba hydrographical region: subsidies to the environmental monitoring of southern Brazilian aquatic systems. Acta Limnologica Brasiliensia 18(1): 9-27.

Lobo, E. \& Leighton, G. 1986. Estruturas de las fitocenosis planctónicas de los sistemas de desembocaduras de rios y esteros de la zona central de Chile. Revista de Biologia Marina 22: 143-170.

Lobo, E.A. \& Torgan, L.C. 1988. Análise da estrutura das comunidades de diatomáceas (Bacillariophyceae) em duas estações do sistema Guaíba, Rio Grande do Sul, Brasil. Acta Botanica Brasilica 1(2): 103-119.

Lobo, E.A.; Callegaro, V.L.M.; Hermany, G.; Bes, D.; Wetzel, C.A. \& Oliveira, M.A. 2004. Use of epilithic diatoms as bioindicators from lotic systems in southern Brazil, with special emphasis on eutrophication. Acta Limnologica Brasiliensia 16(1): 25-40.

Lobo, E.A.; Callegaro, V.L.M.; Oliveira, M.A.; Salomoni, S.E.; Schuler, S. \& Asai, K. 1996. Pollution tolerant diatoms from lotic systems in the Jacuí basin, Rio Grande do Sul, Brasil. Iheringia, Série Botânica 1(47): 45-72.

Lobo, E.A.; Wetzel, C.E.; Ector, L.; Katoh, K.; Blanco, S. \& Mayama, S. 2010. Response of epilithic diatom communities to environmental gradients in subtropical temperate Brazilian rivers. Limnetica 29(2):323-340.

Lund, J.W.G.; Kipling, C. \& Le-Cren, E.D. 1958. The inverted microscope method of estimating algal number and the statistical basis of estimating by counting. Hydrobiologia 11: 143-170.

Magrin, A.G.E. \& Senna, P.A.C. 2000a. Diatomáceas (Bacillariophyta) da lagoa do Diogo e seus trechos fluviais: córrego Cafundó e rio Mogi-Guaçu. 1. Classes Coscinodiscophyceae e Fragilariophyceae (Fragilariaceae). Pp. 403-413. In: Santos, J.E. \& Pires, J.S.R. (Eds.). Estação Ecológica de Jataí. São Carlos, Rima.

Magrin, A.G.E. \& Senna, P.A.C. 2000b. Diatomáceas (Bacillariophyta) da lagoa do Diogo e seus trechos fluviais: córrego Cafundó e rio MogiGuaçu. 2. Classe Bacillariophyceae. Pp. 415-430. In: Santos, J.E. \& Pires, J.S.R. (Eds.). Estação Ecológica de Jataí. São Carlos, Rima.

Margurran, A.E. 1991. Ecological diversity and its measurement. Princenton, Princenton University Press.
Messyasz, B. \& Kuczynska-Kippen, N. 2006. Periphytic algal communities: A comparison of Typha angustifolla L. and Chara tomentosa L. beds in three shallow lakes (West Poland). Polish Journal of Ecology 54: 15-27.

Montuelle, B.; Dorigo, U.; Berard, A.; Volat, B.; Bouchez, A.; Tlili, A.; Gouy, V. \& Pesce, S. 2010. The periphyton as a multimetric bioindicator for assessing the impact of land use on rivers: an overview of the ArdiSres-Morcille experimental watershed (France). Hydrobiologia 657: 123-141.

Nogueira, M.G.; Henry, R. \& Maricatto, F.E. 1999. Spatial and temporal heterogeneity in the Jurumirim Reservoir, São Paulo, Brazil. Lakes \& Reservoirs: Research and Management 4: 107-120.

Power, M.E.; Dietrich, W.E. \& Finlay, J.C. 1996. Dams and downstream aquatic biodiversity: Potential food web consequences of hydrologic and geomorphic change. Environmental Management 20: 887-895.

Pusceddu, A.; Gambi, C.; Manini, E. \& Danovaro, R. 2007. Trophic state, ecosystem efficiency and biodiversity of transitional aquatic ecosystems: analysis of environmental quality based on different benthic indicators. Chemistry and Ecology 23: 505-515.

Relyea, R.A. 2005. The impact of insecticides and herbicides on the biodiversity and productivity of aquatic communities. Ecological Applications 15: 618-627.

Roche, H. \& Boge, G. 1996. Fish blood parameters as a potential tool for identification of stress caused by environmental factors and chemical intoxication. Marine Environmental Research 41: 27-43.

Rodrigues, L. \& Bicudo, D.C. 2001. Similarity among periphyton algal communities in a lentic-lotic gradient of the upper Parana river floodplain, Brazil. Revista Brasileira de Botânica 24: 235-248.

Round, F. E. 1965. The Biology of the algae. London, Edward Arnold (Publishers) Ltd.

Salomoni, S.E.; Rocha, O.; Callegaro, V.L. \& Lobo, E.A. 2006. Epilithic diatoms as indicators of water quality in the Gravataí river, Rio Grande do Sul, Brasil. Hydrobiologia 559: 233-246.

Salomoni, S.E.; Rocha, O.; Hermany, G.; Lobo, E.A. 2011. Application of water quality biological indices using diatoms as bioindicators in the Gravataí river, RS, Brazil. Brazilian Journal of Biology 4(71): 949-959.

Silva, S.R.V.F. \& Cecy, I.I.T. 2004. Desmídias (Zygnemaphyceae) da área de abrangência da Usina Hidrelétrica de Salto Caxias, Paraná, Brasil, I: Gênero Cosmarium. Iheringia, Série Botânica 59(1): 13-26.

Smith, W.S. \& Petrere-Jr, M. 2008. Spatial and temporal patterns and their influence on fish community at Itupararanga Reservoir, Brazil. Revista de Biologia Tropical 56: 2005-2020.

Souza, M.G.M. \& Moreira-Filho, H. 1999. Diatoms (Bacillariophyceae) of two aquatic macrophyte banks from Lagoa Bonita, Distrito Federal, Brazil, I: Thalassiosiraceae and Eunotiaceae.Bulletin du Jardin botanique national de Belgique 67: 259-278.

Taniguchi, G.M.; Bicudo, D.C. \& Senna, P.A.C. 2005. Gradiente litorâneo-limnético do fitoplâncton e focoperifíton em uma lagoa da planície de inundação do Rio Mogi-Guaçu. Revista Brasileira de Botânica 28(1): 137-147.

Taniguchi, G.M.; Peres, A.C.; Senna, P.A.C. \& Compère, P. 2003. The desmid genera Cosmarium, Actinotaenium and Cosmocladium from an oxbow lake, Jataí Ecological Station (Southeastern Brazil). Systematics and Geography of Plants 73(1): 133-159.

Thornton, K.W.; Kimmel, B.L. \& Payne, F.E. 1990. Reservoir limnology ecological perspectives. New York, Wiley.

Verb, R.G. \& Vis, M.L. 2005. Periphyton assemblages as bioindicators of mine-drainage in unglaciated western Allegheny plateau lotic systems. Water, Air and Soil Pollution 161: 227-265.

Vercellino, I.S. \& Bicudo, D.C. 2006. Periphytic algal community succession in a tropical oligotrophic reservoir (Sao Paulo, Brazil): comparison between dry and rainy periods. Revista Brasileira de Botânica 29: 363-377.

Vieira, L.C.G.; Bini, L.M.; Velho, L.F.M. \& Mazao, G.R. 2007. Influence of spatial complexity on the density and diversity of periphytic rotifers, microcrustaceans and testate amoebae. Fundamental and Applied Limnology 170: 77-85. 